\title{
Degree of prevalence of different song types of chaffinch (Fringilla coelebs L.) in populations of the European Russia
}

\author{
Olesya Anatolyevna Astakhova
}

Department of Vertebrate Zoology, M. V. Lomonosov Biology Faculty, Moscow State University, Russia, Moscow; chaffinch@bk.ru

Received 12 November 2013; revised 21 December 2013; accepted 9 January 2014

Copyright (C) 2014 Olesya Anatolyevna Astakhova. This is an open access article distributed under the Creative Commons Attribution License, which permits unrestricted use, distribution, and reproduction in any medium, provided the original work is properly cited. In accordance of the Creative Commons Attribution License all Copyrights (C) 2014 are reserved for SCIRP and the owner of the intellectual property Olesya Anatolyevna Astakhova. All Copyright (C) 2014 are guarded by law and by SCIRP as a guardian.

\section{ABSTRACT}

When studying song organizations of chaffinch (Fringilla coelebs L.), we find the unique typological parities (ratio) of songs in different local populations of a species-specific area. The degree of prevalence of different chaffinch song types can't correspond to percentage proceeding from their general (common) number in a population. Thus different areas of Russia are forming original (different) song cultures of chaffinch, consisting of the certain set and a parity (ratio) of song types, frequently including the so-called dialect song forms, that have been observed. The complex interrelation of geographical variability and structural variability of chaffinch song in many respects gives a support in an evolutionary view from the given aspect.

\section{KEYWORDS}

\section{Species-Specific Song of Chaffinch; Different Song Types; Song Cultures; Degree of Prevalence of Song Types in Populations}

\section{INTRODUCTION}

Many species of sparrow (Passeriformes) males have repertoires from two and more variants of species-specific song [1]. Some variants or types of songs are individually various and divided (shared) between individuals of a population [2,3]. According to the proof from many laboratory researches, the distributed (allocated) song type arises through vocal imitation [4]. It is interesting, as this process operates in distribution of different types of songs of chaffinch (Fringilla coelebs L.). The samples of the songs, which have been recorded in sev- eral local populations of chaffinch in territory of distribution of a species, are investigated.

One of the problems (tasks) has consisted in revealing geographical variability of chaffinch song. Thus an attempt to establish macro geographical distribution and a variety of song types are done (made). Most the general (common) and widely widespread types of songs of chaffinch are compared in structural variability in local territory to variability of the certain area of distribution of a species. In studying the microgeographical distribution of chaffinch song in local territory, dividing (sharing) the general (common) types of songs into small distance between males comes to light.

There are questions: as far as different song types of chaffinch are distributed independently from each other, whether there are rare songs in an equal parity (ratio) in different territories. Individuals of chaffinch males in the repertoire can have 1 - 6 types (variants) of species-specific song. Usually the song of chaffinch will consist of three parts: started singing (it is heard as the row of whistle sounds of high tone), elements of the trill (sounds are quickly poured each other and usually tone hardly is lower) and a sharp short stroke in the end [5-7].

Young chaffinch (up to 1 year of life) has the first homogeneous elements of the song pattern and it complicates afterwards (appearing plastic types of songs, capable to change, song elements become differentiated). But for the adult chaffinch male ( 2 - 3 years of life), song species-species pattern is installed (stage of crystallization) and it is different in form elements (at sonogramms), consisting of three distinct parts: started singing, trill, a final stroke (that may be are genetically determined).

\section{MATERIAL AND METHODS}

In northwest (Curonian spit, the Kaliningrad region) and central (Zvenigorod, Moscow, Michurinsk) parts of 
the European Russia have been made tape recorder records of singing males of chaffinch during the springand-summer period of 2005-2006 ( $\mathrm{N}=218$ males). Different local populations of chaffinch (Fringilla coelebs L.), researched by us, are removed approximately on $1000 \mathrm{~km}$ from each other.

Further, sonograms of songs were analyzed with the help of computer program Avisoft-SaSLab Light. In total it has been analyzed about five thousand songs. The songs similar in two or all three parts (started singing, a trill, and a final stroke) we considered as one type. Types of songs were marked by Latin letters.

In samples on Curonian spit (the Kaliningrad region) ( $\mathrm{N}=158$ males) we allocate (distinguish) 22 types of songs (A B C D E F G H J I K L M N O P Q R S T U V). At record, songs of one type met in different points of territory (was considered, that belong to repertoires of different males), therefore alongside with the letter were designated by numbers in ascending order (for example, A1, A2, A3, etc.).

In populations of the central part of the European Russia ( $N=65$ males) 15 different types of songs (A B C D
F G I J M N S U V W Y), from which 12 types of songs were similar in the structure to corresponding types on Curonian spit are found, but frequently they had the modified elements on sonograms, therefore were considered as dialect forms (B C D F G I J M N S U V). Local variants of vocalizations of birds can be considered as analogy of human speech and to name "dialects" [8,9]. It has not been found analogues of six song types (H O E Q $\mathrm{R} \mathrm{T}$ ), and song types $\mathrm{W}, \mathrm{Y}$ appeared new in relation to known to us song patterns on Curonian spit.

Chaffinch inhabits at the forests and areas, where there are trees, bushes (parks, gardens). Chaffinch is migrant on average distances, during the winter it flies away to the South (from the Curonian spit at Kaliningrad region to the South of Europe, from the European part of Russia to the Caucasus, Kazakhstan).

\section{RESULTS AND DISCUSSION}

It is possible to make a percentage parity (ratio) of the typological organization of chaffinch song (Fringilla coelebs L.) in local populations (Table 1).

Table 1. A percentage comparison of chaffinch song types (Fringilla coelebs L.) in different regions of the European Russia.

\begin{tabular}{|c|c|c|c|c|}
\hline \multirow{2}{*}{$\begin{array}{l}\text { Type of song } \\
\text { (token) }\end{array}$} & \multicolumn{2}{|c|}{$\begin{array}{l}\text { Northwest of European Russia } \\
\text { (Curonian spit) }\end{array}$} & \multicolumn{2}{|c|}{$\begin{array}{c}\text { Center of European Russia } \\
\text { (Moscow, Zvenigorod, Michurinsk) }\end{array}$} \\
\hline & $\begin{array}{l}\text { Number of song } \\
\text { types in sample }\end{array}$ & $\begin{array}{l}\text { Percent from the common number } \\
\text { of song type in a population }\end{array}$ & $\begin{array}{l}\text { Number of song } \\
\text { types in sample }\end{array}$ & $\begin{array}{l}\text { Percent from the common number } \\
\text { of song type in a population }\end{array}$ \\
\hline A & 18 & $9.84 \%$ & 8 & $8.6 \%$ \\
\hline B & 5 & $2.73 \%$ & 8 & $8.6 \%$ \\
\hline C & 38 & $20.8 \%$ & 24 & $25.8 \%$ \\
\hline $\mathrm{D}$ & 11 & $6.01 \%$ & 3 & $3.2 \%$ \\
\hline E & 7 & $3.82 \%$ & & \\
\hline F & 16 & $8.74 \%$ & 5 & $5.4 \%$ \\
\hline G & 10 & $5.5 \%$ & 1 & $1.07 \%$ \\
\hline $\mathrm{H}$ & 6 & $3.28 \%$ & & \\
\hline I & 22 & $12.02 \%$ & 11 & $11.83 \%$ \\
\hline $\mathrm{J}$ & 13 & $7.1 \%$ & 12 & $12.9 \%$ \\
\hline $\mathrm{K}$ & 3 & $1.64 \%$ & & \\
\hline L & 1 & $0.5 \%$ & & \\
\hline M & 20 & $10.93 \%$ & 2 & $2.15 \%$ \\
\hline $\mathrm{N}$ & 8 & $4.4 \%$ & 5 & $5.4 \%$ \\
\hline O & 18 & $9.84 \%$ & & \\
\hline $\mathrm{P}$ & 1 & & & \\
\hline $\mathbf{R}$ & 24 & $13.1 \%$ & & \\
\hline $\mathrm{Q}$ & 1 & $0.55 \%$ & & \\
\hline S & 17 & $9.3 \%$ & 2 & $2.15 \%$ \\
\hline $\mathrm{T}$ & 14 & $7.7 \%$ & & \\
\hline $\mathrm{U}$ & 8 & $4.4 \%$ & 3 & $3.2 \%$ \\
\hline V & 2 & $1.1 \%$ & 2 & $2.15 \%$ \\
\hline W & & & 3 & $3.2 \%$ \\
\hline Volume of sample individuals (n) & & 158 & & 65 \\
\hline Volume of sample song types (n) & & 183 & & 93 \\
\hline
\end{tabular}

The note: the volume of sample includes all recorded males in populations (the bottom line); a percentage parity (ratio) expected proceeding from the general (common) number of song types in samples of populations in northwest of the European Russia-183 song types, in the central part of European Russia—93 song types (that is repertoires of males with small samples were taken into account also); thus it is necessary to understand, that songs of one type from everyone male had sample on the average $n>20$; the most widespread (frequently met) in populations song types (with sample $n>15$ ) are allocated by a bold font. ${ }^{*}$ Types of songs could be similar (but individual differentiated) at different males at the sample size (but chaffinch population has only 20 different song type at average). 
Both in northwest, and in the center of the European Russia the most widespread appeared song type C (Figures 1.2 and 1.3). The second on prevalence in local populations the song type I (Figure 1.5) was. Song type $\mathrm{R}$ (Figure 1.9) and song type $M$ (Figures 1.6 and 1.7) are more often, than others met at record only on Curonian spit. But song culture of a population of chaffinch is characterized by different types of songs, which have the big sample size: A, F, S, O, T, J (Figures 1 and 2).

To have more precise representation about types of chaffinch songs, which we discuss, it is possible to cite (to show) sonograms their samples (Figure 1).

At close (attentive) viewing of sonograms (Figure 1) it is possible to allocate (to find) a number (row) of features in structure of songs, characteristic only for the certain song type. It is necessary to remind, that we considered to songs of one type, what are similar on two or all three parts of songs (started singing or whistle elements, a trill and a final stroke), which (every song part) also can include one or two phrases (the elements similar under the form).

The whistle elements (started singing) of chaffinch songs (Fringilla coelebs L.) can be as arc-similar, and narrow linear forms. But on hearing all of them are perceived by higher tone, as if a row of whistle sounds "fuit-fuit-fuit". The trill with equal frequency can consist both of one phrase, and from two phrases. Elements of a trill can be completely different in form, consist of two and more subelements. But if to look narrowly (more attentive), nevertheless it is possible to notice, that in many respects on the structure elements are similaronly their primary basis in different types differently performance at singing. The same is possible to tell about a final stroke-usually sharp on the hearing, consisting from stick-similar of elements on sonograms, has much in common at different types of songs, but also is individual for everyone song pattern.

For full representation of song cultures of different local populations of chaffinch (Fringilla coelebs L.) it is necessary to cite (to show) samples of the most widespread types of songs in territory of the center of the European Russia, which can not coincide with a degree of their prevalence in other populations (Figure 2).

Song type C (Figure 2.1) (its version type $C^{*}$ (Figure 2.2) and song type I (Figure 2.3) appeared in the majority both in samples in northwest, and in the center of the European Russia (Table 1). But song type I (Figure 2.3) - the dialect form in relation to songs of this type on Curonian spit. The song type J (Figure 2.4) also is distributed enough in the center of the European Russia, but in northwest this song type was average on occurrence. Types of songs A, B (Figures 2.5 and 2.6) also have average prevalence. These are the basic song patterns, which frequently met in populations of all two regions of Russia where research.

For comparison we shall result (show, cite) individual types of chaffinch songs (Fringilla coelebs L.) in populations of the central part of the European Russia (Figure 3) (at record met in repertoire of 1 - 2 males).

Rare song types of chaffinch are V, K, Q, L (on Curonian spit) (Figure 4). In the center of the European Russia rare types of songs could be and what are distributed enough in northwest of Russia (G, M, S) (Figure 3), and any types of songs, in comparison with Curonian spit, and did not meet at all (E, H, O, R, T) (Figure 5). It can speak about different and the certain originality of song cultures of different local populations of chaffinch.

Thus, some song types of chaffinch, the most widespread in one local population, could be rare in samples of other population. Probably, as a result of migrations there is a constant mixing vocal traditions $[10,11]$.

Than it is possible to prove a rarity of these types of chaffinch songs (Figures 3, 4, 5.1, 5.3)? Probably, such song structure was not in the greater degree characteristic for species specific song of chaffinch (Fringilla coelebs L.), therefore it had no "support" for the big distribution to "communicative" groups of a population. But can be, it is simple song types of migrants from other populations, which song culture includes their majority.

\section{CONCLUSIONS}

Geographical variability of song is obvious in many species of birds. The typological parity (ratio), which is the a certain set of song patterns in local populations of birds with the big repertoire (it is a lot of types of songs) which is possible to be characterized as mosaic distribution $[12,13]$, but a number (line, row) of researchers do not support the similar description of bird song variability in territory.

It is possible to track changes of bird song from a place to a place and to draw a conclusion that geographical variability is the result of accumulation of mistakes of copying at training of songs (song learning) from generation to generation [14]. But big song repertoires of birds interfere with an objective definition of dialect borders within the limits, of which there is a traditional training of song components, characteristic this population $[15,16]$.

Local populations of birds are formed certain (determined) song cultures, which are capable to change during time and to make vocal dialect forms of birds on all areas of distribution of a species. Steady in time dialects of birds, the phenomenon of conservatism of the vocal traditions has been transmitted to the subsequent generations by means of vocal imitation. For many species of 


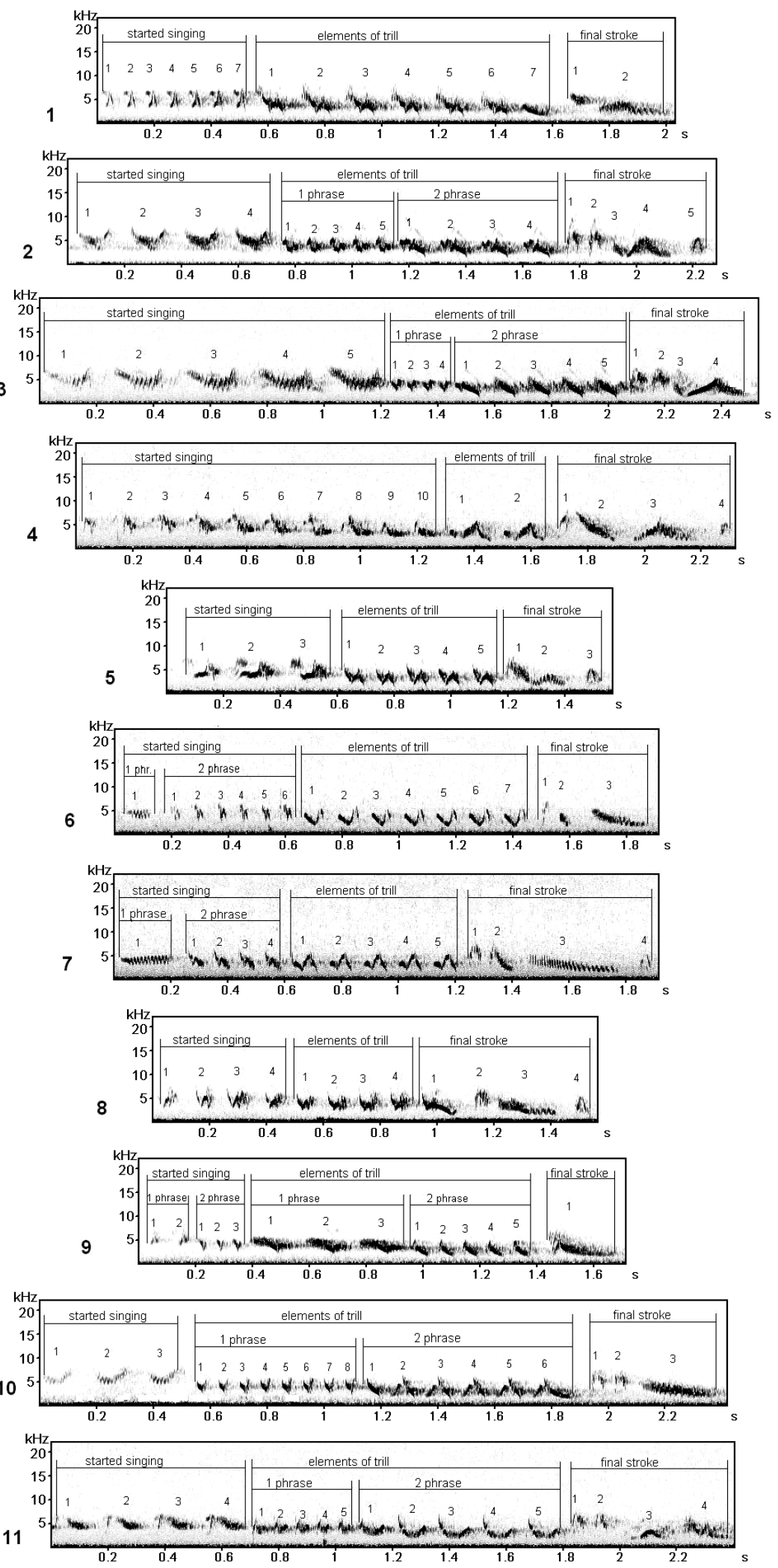

Figure 1. The most widespread types of songs of chaffinch (Fringilla coelebs L.) in a population of northwest of the European Russia (Curonian spit): 1-song type A, 2song type C, 3-song type $\mathrm{C}^{*}$, 4-song type F, 5-song type I, 6-song type M1, 7song type M12, 8—-song type O, 9—song type R, 10 — song type S, 11—song type J. 

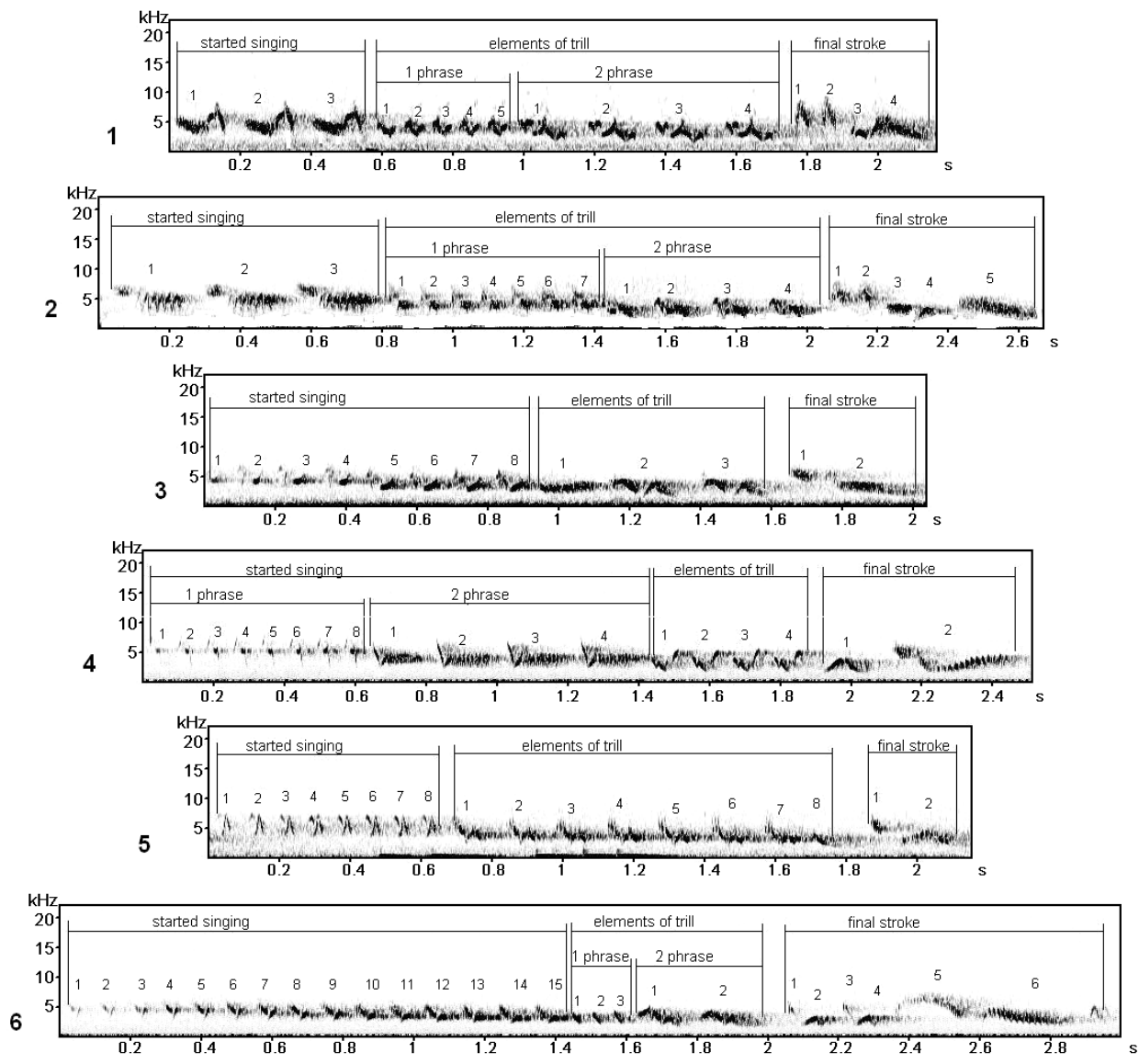

Figure 2. The most widespread types of songs of chaffinch (Fringilla coelebs L.) in populations of the central part of the European Russia: 1-song type C, 2-song type C*, 3- song type I, 4song type J, 5-song type A, 6-song type B.
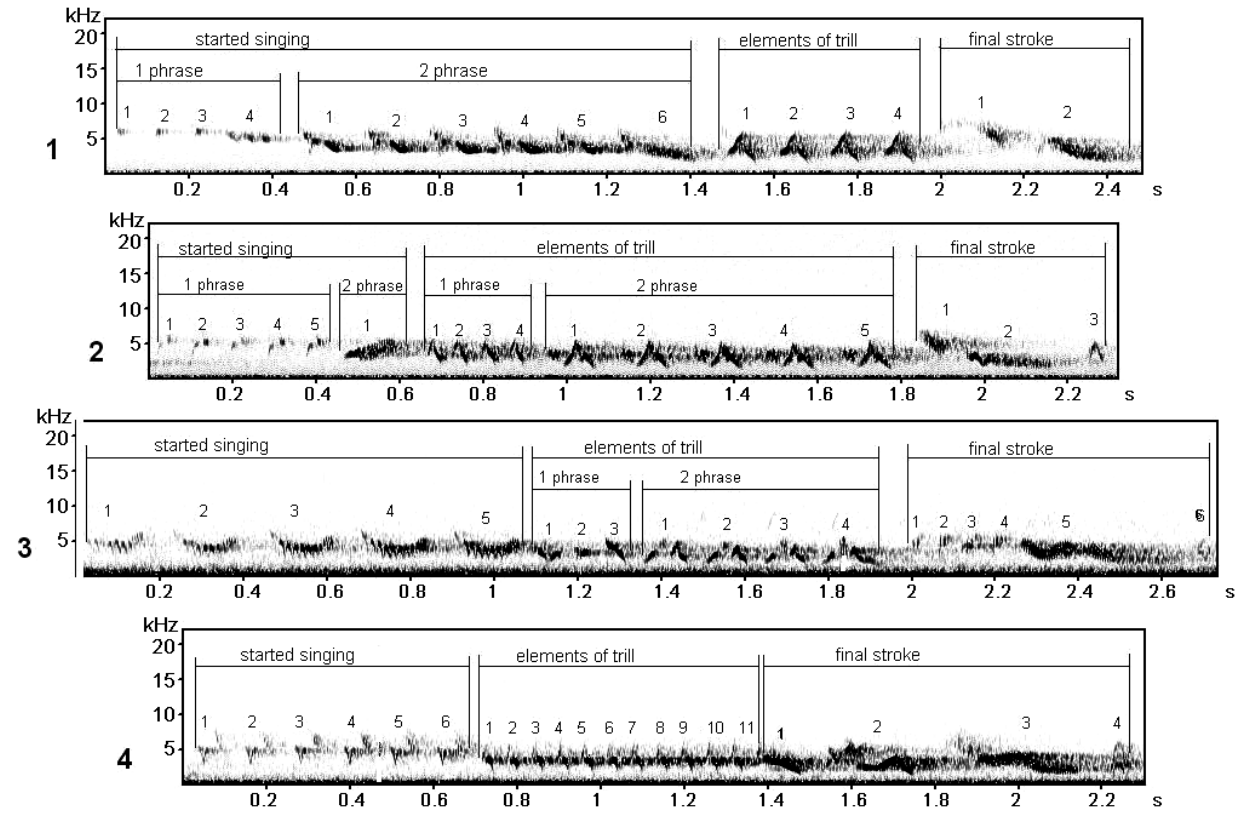

Figure 3. Rare song types of chaffinch (Fringilla coelebs L.) populations of the Central part of the European Russia: 1 -song type G, 2-song type M 1 (record in Michurinsk, the Tambov region), 3—song type S, 4—song type V (record in Zvenigorod, the Moscow region). 


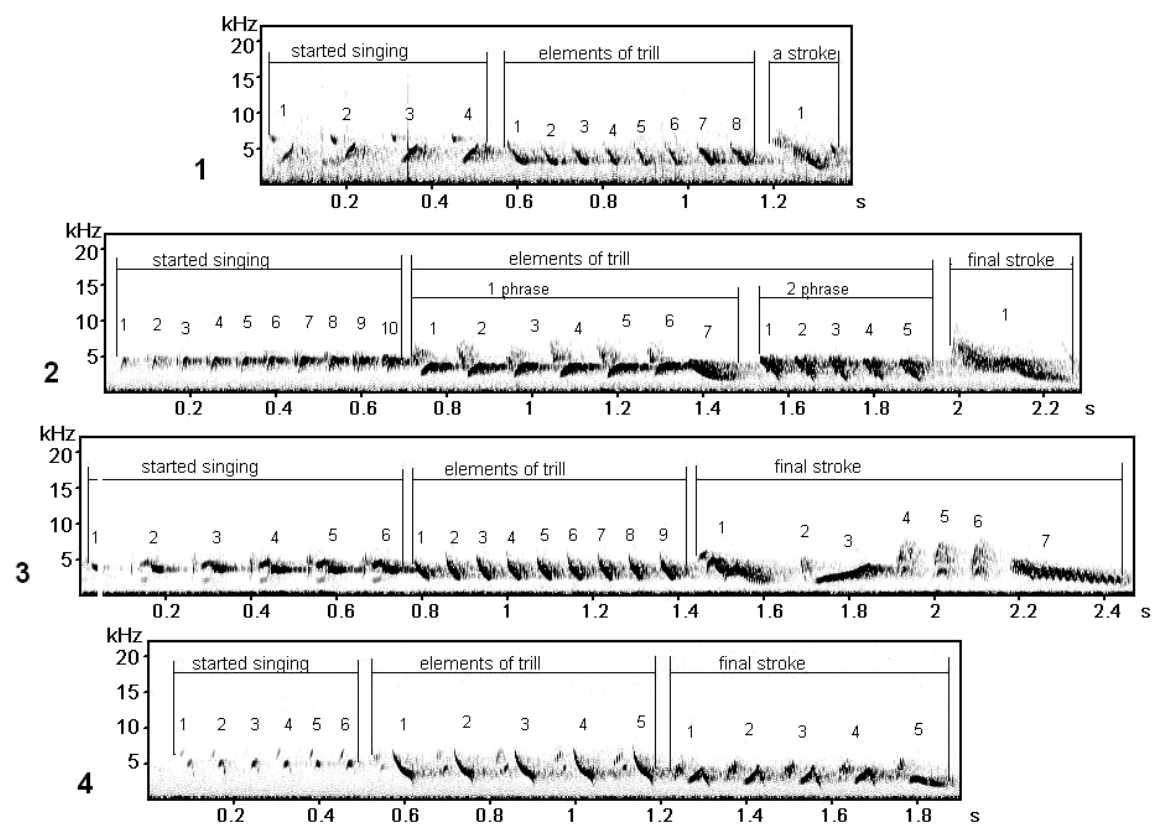

Figure 4. Sonograms of rare song types of chaffinch (Fringilla coelebs L.) (are recorded on Curonian spit, the Kaliningrad region): 1-song type K, 2-song type L, 3-song type V, 4 —song type Q.
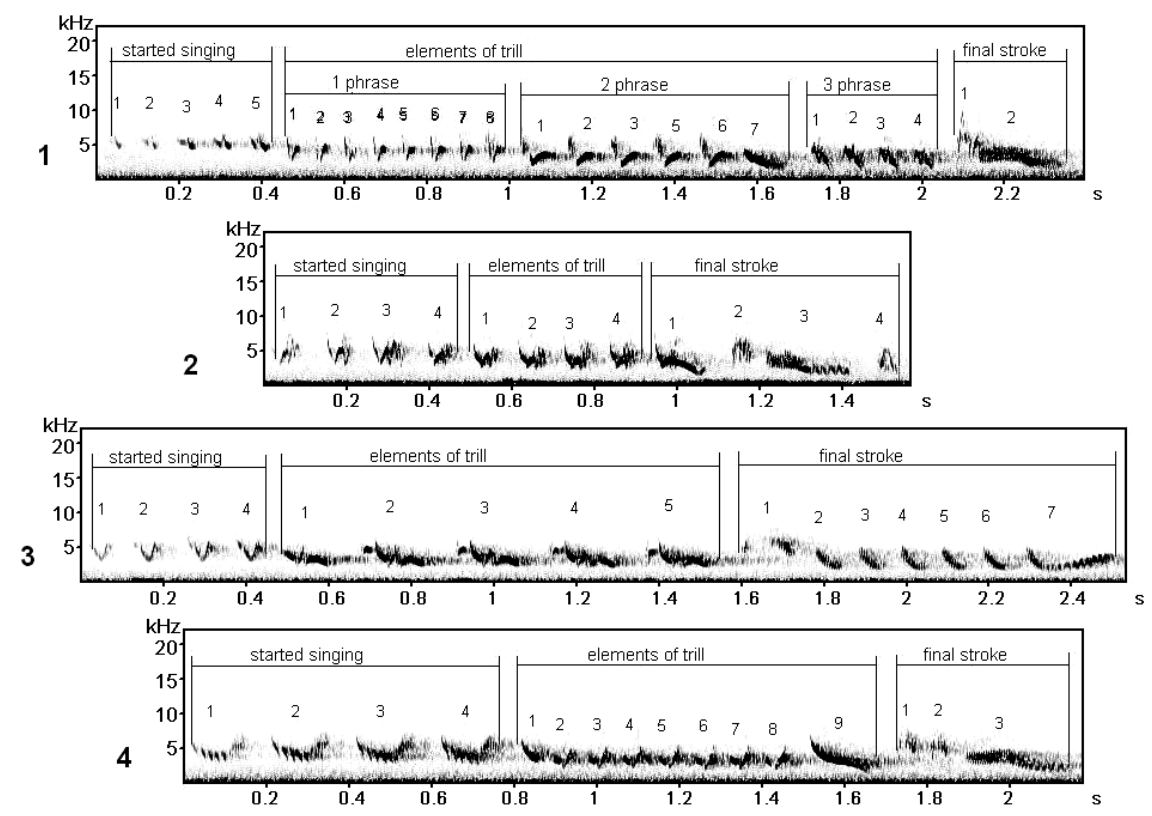

Figure 5. Song types of chaffinch (Fringilla coelebs L.), found only in samples on Curonian spit (the Kaliningrad region): 1-song type H, 2-song type O, 3-song type E, 4 - song type $\mathrm{T}$ (types of songs $\mathrm{H}$ and $\mathrm{E}$ were rare- $-3 \%$ - $5 \%$ of prevalence from all types of songs in a population).

birds, patterns of variability as purchases of vocal traditions are products of cultural evolution.

\section{REFERENCES}

[1] Hartshorne, C. (1973) Born to sing. Indiana University
Press, Bloomington, 132.

[2] Slater, P.J.B. (1981) Chaffinch song repertoires: Observations, experiments and a discussion of their significance. Zeitschrift fur Tiërpsychologie, 72, 177-184.

[3] McGregor, P.K. and Krebs, J.R. (1982) Song types in a population of great tits (Parus major): Their distribution, 
abundance and acquisition by individuals. Behaviour, 79, 126-152. http://dx.doi.org/10.1163/156853982X00210

[4] Kroodsma, D.E. (1978) Aspects of learning in the ontogeny of bird song: where, from whom, when, how many, which and how accurately? Garland, New York, 215-230.

[5] Marler, P. (1952) Variation in the song of the Chaffinch Fringilla coelebs. Ibis, 98, 458-472.

[6] Thorpe, W.H. (1958) The leaning of song patterns by birds, with especial reference to the song chaffinch Fringilla coelebs. Ibis, 100, 535-570. http://dx.doi.org/10.1111/j.1474-919X.1958.tb07960.x

[7] Nottebohm, F. (1969a) The "critical period" for song leaning in birds. Ibis, 111, 386-387. http://dx.doi.org/10.1111/j.1474-919X.1969.tb02551.x

[8] Mundinger, P.C. (1980) Animal cultures and a general theory of cultural evolution. Ethology and Sociobiology, 1, 183-223. http://dx.doi.org/10.1016/0162-3095(80)90008-4

[9] Mundinger, P.C. (1982) icrogeographic and macrogeographic variation in acquired vocalizations of birds. Academic Press, New York, 147-208.

[10] Slater, P.J.B. and Ince, S.A. (1979) Cultural evolution in chaffinch song. Behaviour, 71, 146-166.
http://dx.doi.org/10.1163/156853979X00142

[11] Slater, P.J., Ince, S.A. and Colgan, P.W. (1980) Chaffinch song types: Their frequencies in the population and distribution between repertoires of different individuals. Behaviour, 75, 207-218. http://dx.doi.org/10.1163/156853980X00401

[12] Espmark, Y.O., Lampe, H.M. and Bjerke, T.K. (1989) Song conformity and continuity in song dialects of redwings Turdus iliacus and some ecological correlates. Ornis Scandinavica, 20, 1-12. http://dx.doi.org/10.2307/3676701

[13] Thielcke, G. (1965) Gesangsgeographische Variation des Gartenbaumläufers (Certhia brachydactyla) im Hinblick auf das Artbildungsproblem. Zeitschrift fur Tiërpsychologie, 22, 542-566. http://dx.doi.org/10.1111/j.1439-0310.1965.tb01506.x

[14] Thielcke, G. (1969) Geographic variation in bird vocalizations. Cambridge University Press, London, New York, 311-340.

[15] Catchpole, C.K. (1995) Bird song: Biological themes and variations. Cambridge University Press, Cambridge, 248.

[16] Kroodsma, D.E. (1974) Song learning, dialects, and dispersal in the Bewick's Wren. Tierpsychology, 35, 352-380. 